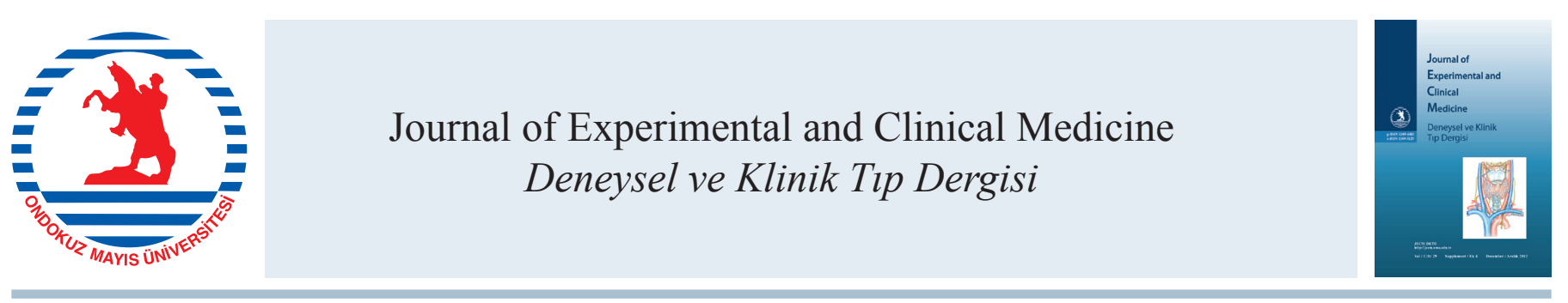

Derleme / Review

doi: $10.5835 /$ jecm.omu.29.s4.022

\title{
Kötü diferansiye tiroit kanserleri
}

\section{Poorly differentiated thyroid carcinomas}

\section{Bekir Kuru}

Ondokuz Mayıs Üniversitesi, Tıp Fakültesi, Genel Cerrahi Anabilim Dall, Samsun, Türkiye

\begin{tabular}{|c|c|c|}
\hline \multicolumn{2}{|c|}{ MAKALE BİLGILERİ } & ÖZET \\
\hline \multicolumn{2}{|c|}{ Makale geçmişi } & Kötü diferansiye tiroit kanserleri (KDTK) minimal diferansiyasyon gösteren ve diferansi- \\
\hline Geliş tarihi & : 07 / 06 / 2012 & ye tiroid tümörleri ile anaplastik lezyonlar arasında orta derecede bir prognoza sahip olan \\
\hline Kabul tarihi & $: 05 / 12 / 2012$ & $\begin{array}{l}\text { tiroid karsinomların belirtmektedir. KDTK genellikle büyük boyutludur ve sıklıkla tanı } \\
\text { anında akciğer veya kemiğe metastaza eşlik eder. Solid, trabeküler veya insüler tipleri }\end{array}$ \\
\hline \multicolumn{2}{|c|}{ * Yazışma Adresi: } & $\begin{array}{l}\text { vardır. En iyi karakterize varyantı insüler karsinomdur. Mitoz sıktır ve nekroz ve vasküler } \\
\text { invazyon odakları vardır. Potansiyel radyoaktif iyot (RAİ) tutulumu nedeniyle tam cer- }\end{array}$ \\
\hline \multicolumn{2}{|l|}{ Bekir Kuru } & rahiden sonra tüm KDTK hastalarında RAİ önerilmektedir. Eksternal radyoterapi (XRT) \\
\hline \multicolumn{2}{|c|}{ Ondokuz Mayıs Üniversitesi, } & tedavisi ile ilgili kanıt eksiktir. Bu temelde KDTK de uzak metastaz olmayan T3 tümörl- \\
\hline \multicolumn{2}{|c|}{ Tıp Fakültesi, } & T4 lerde ve bölgesel lenf nodu metastazı olanlarda XRT önerilmektedir. \\
\hline \multicolumn{2}{|c|}{ Genel Cerrahi A D } & J. Exp. Clin. Med., 2012; 29:S333-S336 \\
\hline
\end{tabular}

55139 Kurupelit, Samsun

e-posta: bekirkuru@gmail.com

\section{Anahtar Kelimeler: \\ Kötü diferansiye tiroit karsinomları \\ Tiroit kanserleri \\ İnsüler tiroit karsinomları \\ Kötü diferansiye tiroit karsinomlarının tedavisi}

\section{Keywords:}

Poorly differentiated thyroid carcinomas

Thyroid carcinomas

Insular thyroid carcinomas

Treatment of poorly differentiated thyroid carcinomas

\begin{abstract}
Poorly differentiated thyroid carcinomas (PDTC) show minimal differentiation and have a moderate prognosis that is between the prognosis of differentiated thyroid carcinomas and anaplastic carcinomas. PTDC generally have a large size usually associate with bone and pulmonary metastasis. PTDC have solid, trabecular and insular variants. The well known variant is insular carcinoma. They are potentially radioactive iodine (RAI) avid and therefore after complete surgery, RAI therapy is suggested for patients with PTDC. Proof for postoperative radiotherapy is poor. However, radiotherapy is offered for T3 tumors without remote metastasis and T4 tumors and for patients with regional lymph node metastasis.

J. Exp. Clin. Med., 2012; 29: S333-S336
\end{abstract}

\section{Giriş}

Kötü diferansiye tiroit kanserleri

$\mathrm{Bu}$ terim, minimal derecede diferansiyasyon gösteren ve diferansiye tiroit tümörleri ile anaplastik lezyonlar arasında orta derecede bir prognoza sahip olan tiroit karsinomlarını belirtmektedir. Kötü diferansiye tiroit kanserleri (KDTK) genellikle büyük boyutludur ve sıklıkla tanı anında akciğer veya kemiğe metastaza eşlik eder. Mikroskopik büyüme örneği solid, trabeküler veya insüler olabilir. Mitoz sıktır ve nekroz ve vasküler invazyon odakları vardır. En iyi karakterize varyantı tümör hücrelerinin, fibröz doku ile ayrılan keskin bir şekilde sınırlanmış adalarda büyüdüğü insüler karsinomdur (Volante ve ark., 2007; Malloy ve Cunnane, 2008).

$\mathrm{Bu}$ heterojen malign tiroit tümörleri foliküler epitelden kaynaklanan (sıklıkla papiller veya foliküler karsinom ile birlikte bulunan) orta-yüksek mitotik aktiviteye sahiptir, görece uniform epitelyum hücrelerinin solid kitleler veya trabekülalarından oluşur, değişken sayıda varolan küçük foliküller içerir ve akut nekroz bölgeleri içerebilir (Akslen ve LiVolsi, 2000). KDTK nadir rastlanan ve iyi diferansiye tiroit kanserlerinden (IDTK) daha kötü prognoz taşır. Bir grup tiroit tümörünün varlığının kötü diferansiye tiroit kanseri olarak tanımlanması ilk kez birbirinden bağımsız olarak 1983' de Sakamato ve ark. ve 1984 'te Carcangiu ve ark. tarafindan önerilmişlerdir. Cerrahlar ve endokrinolojistler için fark edilmesi ve agresif tedavi seçeneklerinin dikkate alınmasında güçlükler içerir. Histopatolojik tanımlanmasında konsensus yoktur. Bazı seriler IDTK' nin daha kötü prognoz eğilimli 
tall cell, kolumnar, diffüz sklerozan, trabeküler ve onkositik lezyonları ve Sakamoto'nun kötü diferansiye karsinomu gibi tiplerini de içerir (Sakamoto, 2004). İTK' li hastaların bazı alt gruplarına undiferansiye tümörler olarak yanlış tanı konulabilir. İDTK' nın sadece insüler, trabeküler ve solid tipleri dahil edilirse Kuzey Amerika'da tiroit kanseri hastalarının \% 2-3'ü (fakat kuzey İtalya'da tiroit kanseri hastalarını \% 15'e kadarı) etkilenir. KDTK' nin Kuzey Amerika'da yaşayan İtalyan kökenlilerde sık olmaması çevresel faktörlerin (olasılıkla iyot gibi diyet faktörleri) bu lezyonların oluşumunda önemli rol oynadığını göstermektedir (Volante ve ark., 2007). KDTK prognozu IDTK ile anaplastik tiroit kanserlerinin prognozları arasında bir yere düşen folikül kaynaklı bir tümördür. KDTK tanı anında, çoğu IDDTK dan daha yüksek lokal invazyon oranına sahip olduğundan dolayı, önemli ve olumlu prognostik gelişime yol açan uygun cerrahi planlama ve tüm gros hastalığın tam rezeksiyonu için en iyi şansa olanak verdiği için vokal kord fonksiyonunun preoperatif değerlendirmesi çok önemlidir (Sanders, 2007). KDTK' nın cerrahi sonrası tedavisi ile ilgili literatür sınırlıdır. Günümüz literatürünün çoğu çok az hasta sayısını içeren retrospektif serilerdir.

\section{Kötü diferansiye tiroit karsinomunun patolojik tanı- mı ve patolojisi}

Papiller/foliküler ve anaplastik karsinom arasindaki bir orta grade karsinom kavramı tiroit kanserleri başka sistem kanserleri ile karşıllaştırılırsa anlam kazanır. Ancak, yıllarca bu grup neoplazilerin fark edilmesi ve tanımı net değildi. Aslında birçok patolog onlara foliküler karsinoma başlığ altında tanı koymuştur. Diğerleri anaplastik karsinomun bir şekli olarak dikkate almış ve bazılarını küçük hücreli karsinom olarak sınıflamıştır (Sanders, 2007). Bu grup tümörlerin patolojik tanımlanmasında karışıklık olmasından dolayı tedavi ve prognozu net değildir. Bu durum problemler üretir, çünkü net ve tek tip tanımlar olmaksızın kanıta dayalı olmayan kararlar mümkündür.

$1983^{\prime}$ te Sakamoto ve ark. Japonya deneyimini yayınladı ve prognoz anlamında orta düzeyde lezyon grubunu tanımlad. Ancak onlar ve Japonya'dan diğerleri papiller karsinomun tall cell, diffüz sklerozan, kolumnar hücreli ve solid alt tipler olarak tanımlanan lezyonlarını kötü diferansiye karsinomlara (KDTK) dahil ettiler (Sakamoto, 2004). Bu siniflama Hurthle hücreli karsinomu da içermektedir. Carcangiu ve ark. (1984), tiroit tümörlerinin bir klinikopatolojik çalışmasında histolojik büyüme örneğine dayanarak insüler karsinomu tanımladı. Serilerindeki 25 hastada 5 yıllık mortalite $\% 60^{\prime}$ dı. Kötü prognoza dikkat çektiler. Birçok hastada lezyon ekstratiroidal ve tanıda metastatikti. Sonraki makaleler tanıda tiroide sınır$l_{1}$ ise bu tümörlerin prognozunun daha iyi olduğunu bildirdi. Birkaç seride ince iğne aspirasyon biyopsisi (İAB) ile erken tanının olanaklı olduğu ve agresif tedavi ile sonucun ilk bildirimlerden daha iyi olabileceği ileri sürüldü. Yine de mortalite oranı hala iyi diferansiye papiller ve foliküler karsinomdan anlamlı olarak daha yüksektir. Patolojik olarak insüler, primordial hücreli, intermediate tip veya sadece kötü diferansiye adları altında tanımlanmıştır. Gros olarak genellikle büyük (ortalama 4-5 cm), kısmen kapsüllü olabilir ve nekroz odakları gösterebilirler. Bazı olgularda büyük venleri tutan belirgin vasküler invazyon görülebilir.

İtalya'da 2006' da Turin konsensusu KDTK için bir tanım önerdi: Bu lezyonlar foliküler hücre tipi kaynaklıdır (me- düller kanser bu gruba dahil değildir); immünohistokimya (IHK) ile fokal ve zayıf olsa da tiroglobulin (Tg) üretebilirler (Volante, 2007). Patolojik olarak sitoplazmaya göre yüksek oranda nükleus içeren primitif görünümlü tümör hücrelerinin yuvalar, insulalar (adacıklar, solid kümeler) veya trabekülalarından oluşmuştur. Önemli bir patolojik özellik tümör nekrozunun varlığıdır. Mitotik aktivite kolaylıkla fark edilir. Lenfovasküler invazyon ve çevre dokunun veya tiroit dışı yumuşak dokunun belirgin invazyonu sıktır.

Turin konsensusuna göre KDTK' in olması zorunlu özellikleri:

1. Solid, trabeküler ve insüler büyüme örneğinin varlığı,

2. Papiller kanserin konvansiyonel nükleer özelliklerinin yokluğu ve,

3. Sarmal çekirdekçik (sarmal veya kuru üzüm benzeri düzensiz konturlu), mitotik aktivite $\geq 3 \times 10$ BBA (büyük büyütme alanı) veya nekrozdan en az birisinin varlığıdır.

Sarmal çekirdekçik önceden varolan papiller kanserin dediferansiyasyonunun bir belirtisi olarak yorumlanır (Volante ve ark., 2007). İnsüler terimi lezyonun histolojik büyüme örneğini tanımlar ve bir anlamda karsinoid benzeridir (Baloch ve LiVolsi, 2007). KDTK önceden tedavi edilmiş bir IDTK' nin yinelemesinde oluşabilir veya az diferansiye lezyonun tanı anında tümörün bazı bölümleri papiller karsinomun (daha nadiren foliküler karsinomun) karakteristik nükleer özellikleri ve büyüme örneğini gösterebilirler. KDTK' ler anaplastik karsinom gibi en başından ortaya çıkabilir veya önceden varolan IDTK' den gelişebilirler (Volante ve ark., 2007). Spektrumun diğer tarafinda KDTK' nin undiferansiye veya anaplastik karsinomlar ile birlikteliği olan bazı olgular tanımlanmıştır. Bu hastalık şekli bir KDTK olarak oluşabilir veya yineleme veya metastazda anaplastik transformasyona uğrar veya iki özellik ilk tanı anında birlikte varolabilirler.

İnsüler karsinomlarda \% 25'e kadar p53 mutasyonları oluşabilir ve IDTK ile anaplastik form arasında genetik bir orta zemini gösterir. KDTK tanısının klinik çıarımları konusunda çalışmalar sınırlıdır ve patolojik tanımdaki güçlük nedeniyle kafa karıştırıcıdır. Ulaşılabilen bilgiler KDTK' nin enkapsülasyon olmaması, tiroit dışı büyüme, nekroz ve fazla mitotik aktivite gibi kötü bir görünüme eşlik ettiğini göstermektedir.

\section{Klinik özellikler}

Tüm tiroit kanserlerinin \% 10'una kadarını oluşturabilirler, Avrupa'da Amerika'ya göre daha sıktır ve erkek/kadın oranı 1:2' den yüksektir (Patel ve Shaha, 2006). KDTK' nın IDTK ile anaplastik arasında orta derecede agresif davranışlı klinik özellikleri vardır. IDTK' deki minör bir KDTK bileşeninin IDTK' in prognozunu kötüleștirip kötüleștirmediği bilinmiyor (Patel ve Shaha, 2006). Decaussin ve ark.'nın (2002) göre insüler bileșen varlığı bağımsız prognostik bir faktördür. Ashfaq ve ark.'nın (1994) göre insüler bileşen ileri yaş ile koreledir. Bu tümörlerin agresif doğasından dolayı çoğu yazar total tiroidektomin gerekli olduğunu savunmaktadır. KDTK' nin \% 50'sinden fazlasinda bölgesel lenf nodu metastazı olması nedeniyle olası bir lateral boyun disseksiyonu ile birlikte santral boyun disseksiyonu da göz önüne alınmalıdır. RAİ, XRT ve kemoterapi hala tartışmalıdır (Patel ve Shaha, 2006). KDTK'ler foliküler epitelden kaynaklanır ve böylece belirgin bir iyot konsantre etme potansiyeli vardır. Patel ve ark. KDTK' lerin \% 85'e dek ulaşan radioaviditesi (RAİ tutulumu 
yeteneği) olduğunu göstermișlerdir. Kullanımı ve etkinliği prospektif olarak kanıtlı değilse de çoğu yazar RAİ uygulanmasını savunmaktadır, çünkü bu tümörler yüksek oranda bölgesel ve uzak metastaz ile birlikte agresif davranışlı diferansiye epitelyum fonksiyonu sergilerler. Rezeke edilemeyen hastalığı olanlar, tam olmayan bir şekilde eksize edilmiş tümörler ve yerel-bölgesel yinelemeler XRT den yararlanabilir. KDTK de kemoterapotik ajanların kullanımı halen araştırılmaktadır (Patel ve Shaha, 2006). KDTK' nin yineleme ve metastaz eğiliminden dolayı bu hastalar yakın izlem altında olmalıdır. KDTK ile anaplastik kanser ayrımında anahtar rolü olan Tg düzeylerinin seri izlemi yinelemelerin saptanmasında yararlı olabilir. Tekrarlanan RAİ, bilgisayarlı tomografi, ve MR görüntüleme hastalığın genişliğini saptamada önemlidir. Son zamanlarda tiroit kanserinde kullanılan Fluorodeoxyglucose positron emission tomography (FDG PET) değerli bir yöntemdir. Tiroit tümörlerinin ilerleyici dediferansiyasyonu sodyum iyot simporterın ekspresyonunun düşmesi ve iyot konsantrasyonu kabiliyetinin azalması ve yanlış negatif RAİ taraması ile sonuçlanır. İDTK FDG' yi zayıf tutarken KDTK' ler yüksek FDG tutulumu gösterirler (Wang ve ark., 1999).

\section{Kötü diferansiye tiroit kanserinin prognozu}

Medline veritabanında insüler, trabeküler ve solid varyantları içeren anaplastik, tall cell, kolumnar, diffüz sklerozan veya onkositik varyantları içermeyen bir araştırmada KDTK ' nin iyi diferansiye veya anaplastik karsinomdan prognozunun anlamlı olarak farklı olup olmadığını incelendi. Bulunan 4 retrospektif çalışma Turin'den Volante ve ark. nın (2004) 42 yıldaki 2900 malign tiroit tümörü içindeki 183 olguluk çalışma arasında KDTK fokal veya diffüz olsun iyi diferansiyeye göre daha agresif seyir izler (5 ve 10 yıllık sağkalım \% 85 ve $\%$ 67). Yaş $>45$, nekroz varlığ 1 ve mitotik aktivite $>\% 3 /$ BBA kötü prognoza eşlik eder. Bu çalışmanın çekincesi Hurthle hücrelilerinin de KDTK içine alınmasıdır.

Wreesman ve Ghossein (2002) Memorial Sloan-Kettering Cancer Center (MSKCC)' de 1940-1999 arasındaki KDTK ve anaplastik kanserleri gözden geçirdikleri karşılaştırmalı genomik hibridizasyon analizinde iyi diferansiyeden anaplastik karsinoma ilerleyen kromozal anormalliklerin dizinsel birikimini gösterdiler. İyi diferansiyeden kötü diferansiye ve anaplastik kansere gittikçe, artan oranda tiroit dışı yayılım, tümör boyutu, lenf nodu metastazı ve uzak metastazın olduğunu gösterdiler. 5 yıllık sağkalım IDTK de en iyi, KDTK de orta ve anaplastikte en kötü idi ve sirasıyla \% 100, \% 70 ve \% 0 oldu. Tokyo'dan Sakamato ve ark. (1983) den itibaren 186 İDT, 35 KDTK ve 25 anaplastik kanseri karşılaştırdı. Sağkalımda üç hastalık da anlamlı fark vardı ve 5 yıllık sağkalım sirasıyla $\% 95, \% 65$ ve $\% 0$ ve 10 yıllık sağkalım sırasıyla $\%$ 86, \% 34 ve \% 0' d1. İDTK' da kötü diferansiye bileşen prognozu etkileyebilir. \% 10' dan fazla KDTK bileşeni olması sık bölgesel yineleme, uzak metastaz ve kötü prognoza eşlik eder (Chow ve ark., 2002). KDTK' in nadir olması nedeni ile randomize çalışmaların yokluğunda literatürdeki çalışmalar KDTK' nın IDTK ile anaplastik tiroit kanser arasında bir prognozu olduğunu göstermektedir.

\section{Eksternal ışınlı radyasyon terapisi}

Eksternal ışın demeti ile radyoterapinin (XRT) KDTK deki rolü ile ilgili çok az çalışma vardır. Çalışmaların çoğu IDTK ve anaplastik kanser ile ilgilidir. Tiroit dışı yayılım gösteren IDTK da XRT ile yapılan çalışmalarda XRT uygulananlarda daha iyi lokal kontrol ve kansere bağlı sağkalım elde edilmiştir. Prenses Margaret Hastanesinde papiller tiroit kanserinde cerrahiden sonra rezidüel mikroskopik hastalık için XRT uygulanan ve uygulanmayan hastalarda 10 yıllık lokal kontrol oranı \% 93'e \% 78 ve 10 y1llık nedene özgü sağkalım \% 81'e \% 65 olmuştur (>60 yaş, gros rezidüel hastalık olmadan tiroit dışı yayılım olanlarda) (Chow ve ark., 2002). Almanya'da $<40$ yaş ve tiroit dışı yayılım olan 137 hastada tiroit yatağ 1 ve servikal ve üst mediasten lenf nodlarına 50-60 Gy RT uygulanan 85' inde anlamlı olarak daha az lokal ve bölgesel yineleme ortaya çıktı (Farahati ve ark., 1996). >45 yaşta ve geniş tiroit dışı yayılımı olan ve gros olarak tam rezeksiyon yapılan IDTK (T4a ve T4b lezyonlar) ve postoperatif gros rezidüel hastalık olan IDTK hastaları yüksek lokal yineleme riski altındadır ve cerrahi ve RAİ sonrasında XRT den yarar görebilirler. Buradan çıkarak yüksek lokal yineleme riski altındaki, özellikle tiroit dışı yayılımı olan ve RAI tutulumu olasılığının düşük olduğu KDTK' ler de cerrahiden sonra XRT den yarar görecektir (Patel ve Shaha, 2006). Kötü diferansiye T3 kanserde (minimal tiroit dışı yayılım nedeniyle T3 olan) ve kapsül dış1 lenf nodu invazyonu veya yaygın lenf nodu tutulumu olan KDTK' lerde de XRT göz önüne alınabilir. Uzak metastaz varlığında KDTK de XRT uygulaması metastaz palyasyonunda veya boyunda kontrol edilemeyen hastalık ile sinırlıdır.

Cerrahi sonrası gros palpe edilebilir hastalığı olan DTK XRT' den yararlanabilir. 126 hastalı bir seride XRT verilen 69 hastada lokal bölgesel kontrol verilmeyenlerden anlamlı olarak daha iyi oldu (10 yılda \% 56 ya \% 24) (Chow ve ark., 2002). Bundan dolayı rezeke edilemeyen KDK' li hastalarda boyunda kontrol edilemeyen hastalığı önlemek için XRT uygulanmalıdır. U şekilli tiroit yatağı volümünde intensity modulated radiotherapy (IMRT) en iyi tekniktir.

Kötü diferansiye kanserde cerrahi sonrası ve cerrahi olmayan tedavi seçenekleri

Anaplastik veya diferansiye tiroit kanseri alt tiplerini içermeyen insüler, trabeküler veya solid varyantları içeren KDTK' de yapılan literatür taramasında postoperatif ve cerrahi olmayan tedavilerle ilgili 3 çalışmaya rastlanmıştır (Sanders, 2007, Auersperg, 1990, Lai, 2006). Osaka Univ. Auersperg ve ark. 1983-90 arasındaki 34 inoperabl KDTK serisinde 34 hastaya kemoterapi vermişlerdir. Yanıt zayıfsa veya cerrahi yapıldıysa cerrahiden sonra XRT önerilmiştir. Anaplastiklerde kemoradyasyona yanıt çok az iken KDTK' de yanıt oranı \% 56 olmuştur ve bazılarında cerrahiye gerek kalmamıștır. Lai ve ark. (2006) Taiwan'da 1991-2005 arasında 1402 hasta arasında 9 insüler tiroid kanserini ve medline taramasındakilerle birlikte 82 hastayı incelediler. İnsüler kanserde lenf nodu metastazı \% 49, ortalama 84,5 aylık izlemde hastalığa özgü ölüm oranı \% 38 ve 5 ve 10 yıllık sağkalım oranlar1 \% 72 ve \% 52 oldu. RAİ ve XRT' nin sağkalımı artırmadığı ortaya çıktı.

\section{Sonuçlar}

Bu gruba diferansiye tümörlerin kötü prognozlu alt tipleri olan tall cell, kolumnar hücreli, diffüz sklerozan ve onkositik tipler alınmamalıdır. KDTK IDTK' den anaplastik kansere malign genetik bir ilerlemenin modelini temsil ediyor görünmektedir. KDTK aslında prognostik anlamda IDTK ile anap- 
lastik arasında yer alır. IDTK' nin çoğunluğunda prognoz tedaviden bağımsız olarak çok iyidir ve agresif tedavi çoğu kez yararsızdır. Anaplastik kanserde tedavi ile ilgisi olmayan bir şekilde prognoz çok kötüdür. KDTK bu anlamda ortada yer alır. Uygun agresif tedavi uygulandığında önemli yarar sağlanabilir. Preoperatif laringoskopi KDTK'lerin 3/4'üne dek görülen tiroit dışı yayılımın saptanmasında çok yararlıdır. $\mathrm{Bu}$ bilgi havayolunu da içeren genişlemiş tiroit rezeksiyonunun planlanması ve intraoperatif nöral izlem ile geri kalan rekürrensin fonksiyonunun korunmasına yol açar (Sanders ve ark., 2007).

Potansiyel RAİ tutulumu nedeniyle tam cerrahiden sonra tüm KDTK hastalarında RAİ önerilmektedir. Postoperatif XRT tedavisi ile ilgili kanıt eksiktir. XRT uygulanması için tavsiye, IDTK' nin kötü prognozlu şekillerine uygulanan ve önemli yararı gösterilmiş XRT çalışmalarından çıkarıma dayanmaktadır. Bu temelde KDTK' de uzak metastaz olmayan T3 tümörlerde, tüm T4'lerde ve bölgesel lenf nodu metastazı olanlarda XRT önerilmektedir (Sanders ve ark., 2007). Eğer cerrahinin tam yapıldığ düşünülüyorsa (yani postoperatif boyunda gros hastalık kalmamış ise) önce RAİ verilmelidir. Eğer cerrahi tam değilse (boyunda postoperatif gros hastalık kalmış ise) en uygunu XRT uygulamaktır. İnoperabl KDTK' de XRT ile veya tek başına yoğun kemoterapi ile ilgili kısa izlemli düzey III kanıtlı çalışmalarda önemli tedavi yanıtı ile bazı hastalarda hastalıksızlık ve diğerlerinde de operabl hastalık durumu ortaya çıkmıştır.

\section{KAYNAKLAR}

Akslen, L.A., LiVolsi, V.A., 2000. Poorly diffentiated thyroid carcinoma- it is important. Am. J. Surg. Pathol. 24, 310-313.

Auersperg, M., Us-Krasovec, M., Petric, G., Pogacnik, A., Besic, N., 1990. Results of combined modality treatment in poorly differentiated and anaplastic thyroid carcinoma. Wien. Klin. Wochenschr. 102, 267-270.

Ashfaq, R., Vuitch, F., Delgado, R., Albores-Saavedra, J., 1994. Papillary and follicular thyroid carcinomas with an insular component. Cancer. 73, 416-423.

Baloch, Z.W., LiVolsi, A.V., 2007. Thyroid pathology. In: (eds.) Oertli D, Udelsman R. Surgery of the thyroid and parathyroid glands. SpringerVerlag Berlin Heidelberg. pp 110-145.

Carcangiu, M.L., Zampi, G., Rosai, J., 1984. Poorly diffentiated ("insular") thyroid carcinoma. Am. J. Surg. Pathol. 8, 655-668.

Chow, S-M., Law S.C.K., Mendellhan, W.M., Au, S.K., Chan, P.T., Leung, T.W., Tong, C.C., Wong, I.S., Lau, W.H., 2002. Papillary thyroid carcinoma: Prognostic factors and the role of radioiodine and external radiotherapy. Int. J. Radiat. Oncol. 52, 784-795.

Decaussin, M., Bernard, M.H., Adeleine, P., Treilleux, I., Peix, J.L., Pugeat, M., Tourniaire, J., Berger, N., 2002. Thyroid carcinoma with distant metastasis. A review of 111 cases with emphasis on the prognostic significance of an insular component. Am. J. Surg. Pathol. 26, 10071015.

Farahati, J., Reiners, C., Stuschke, M., 1996. Impact of adjuvant externa radiotherapy in patients with perithyroidal tumor infiltration (stage pT4). Cancer. 77, 172-180.

Lai, H.W., Lee, C.H., Chen, J.Y., Tseng, L.M., Yang, A.H., 2006. Insular thyroid carcinoma: collective analysis of clinicohistologic prognostic factors and treatment effect with radioiodine or radiation therapy. J. Am. Coll. Surg. 203, 715-722.

Malloy, K.M., Cunnane, M.F., 2008. Pathology and cytologic features of thyroid neoplasms. Surg. Clin. N. Am. 17, 57-70.

Patel, K.N., Shaha, A.R., 2006. Poorly differentiated and anaplastic thyroid cancer. Cancer Control. 13, 119-128.

Sakamoto, A., Kasai, N., Sugano, H., 1983. Poorly diffentiated thyroid carcinoma of thyroid. Cancer. 52, 1849-1855.

Sakamoto, A., 2004. Definition of poorly diffentiated carcinoma of thyroid: The Japanese experience. Endocr. Pathol. 15, 307-311.

Sanders, E.M., LiVolsi, V.A., Brierly, J., Shin, J., Randolph, G.W., 2007. An evidence-based review of poorly diffentiated thyroid cancer. World J. Surg. 31, 934-945.

Wang, W., Macapinlac, H., Larson, S.M., Yeh, S.D., Akhurst, T., Finn, R.D., Rosai, J., Robbins, R.J., 1999. [18F]-2-fluoro-2-deoxy-D-glucose positron emission tomography localizes residual thyroid cancer in patients with negative diagnostic (131) I whole body scans and elevated serum thyroglobulin levels. J. Clin. Endocr. Metab. 84, 2291-2302.

Wreesman, V., Ghossein, R., 2002. Genome-wide appraisal of thyroid cancer progression. Am. J. Pathol. 161,1549-1556.

Volante, M., Collini, P., Nikoforov, Y., Sakamoto, A., Kakudo, K., Katoh, R., Lloyd, R.V., LiVolsi, V.A., Papotti, M., Sobrinho-Simoes, M., Bussolati, G., Rosai, J., 2007. Poorly differentiated thyroid carcinoma: The Turin proposal for the use of uniform diagnostic criteria and an algorithmic diagnostic approach. Am. J. Surg. Pathol. 31, 1256-1264.

Volante, M., Landolfi, S., Chiusa, L., Palestini, N., Motta, M., Codegone, A., Torchio, B., Papotti, M.G., 2004. Poorly differentiated carcinomas of thyroid with trabecular, insular and solid patterns. A clinico-pathological study of 183 cases. Cancer. 100, 950-957. 